\title{
Ultrasound examination of neonatal hip: correlation of twin pregnancy and congenital dysplasia
}

\author{
O Rühmann ${ }^{1}$, D Lazović ${ }^{1}, \mathrm{P}$ Bouklas ${ }^{2}, \mathrm{~S} \mathrm{Schmolke}^{1}$ and $\mathrm{CH}$ Flamme $^{1}$ \\ ${ }^{1}$ Orthopaedic Department, Hannover Medical School, Hannover, Germany \\ ${ }^{2}$ Department of Surgery, Versmold Hospital, Versmold, Germany
}

\begin{abstract}
Twin pregnancy is considered to be a risk factor for congenital dysplasia of the hip. From 1987 until 1996, the hips of 4476 (2260 male, 2216 female) newborn babies were examined by ultrasound according to Graf's technique and classification in our hospital. In this study, we compare the results of twins and singletons for this risk factor. Of the newborns, $97(2.2 \%)$ were twins (40 male, $57 \mathrm{female}$ ); 39 pairs of twins ( $10 \mathrm{mal} \mathrm{e} / \mathrm{male}, 19 \mathrm{femal} \mathrm{e/female,} 10 \mathrm{mal} \mathrm{e} / \mathrm{femal}$ ) and 19 individual twins (6 male, 13 female) were investigated. Hips of typela, Ib and IIa $\left(\alpha \geq 55^{\circ}\right)$ are not pathologic; hips of typella $\left(\alpha<55^{\circ}\right)$ need an early control examination; and hips of typellc, D, IIIa, IIIb and IV require therapy. Types Ia, Ib, and IIa $\left(\alpha \geq 55^{\circ}\right)$ were found in $4207(94.0 \%)$ of all newborns, in $4112(93.9 \%)$ of the singletons, and in $95(97.9 \%)$ of the twins. Early control examination and/or therapy (indicated for typesIIa $\left(\alpha<55^{\circ}\right)$, IIc, D, IIIa, IIIb, and IV) were necessary in $269(6.0 \%)$ of all cases, in $267(6.1 \%)$ of singletons and two $(2.1 \%)$ of twins. Twins with additional factors such as breech position birth, hip dysplasia in the family or premature birth did not show the types of hip IIa $\left(\alpha<55^{\circ}\right)$, IIc, D, IIIa, IIIb, IV. We did find these hips in two (3.5\%) of the female twins, but not at all in the male twins. Statistically, twins with or without other risk factors that are known before birth did not show significantly more of type hip IIa $\left(\alpha<55^{\circ}\right)$, IIc, D, IIIa, IIIb, IV (P > 0.05). Twin Research (2000) 3, 7-11.
\end{abstract}

Keywords: Ultrasound, screening, congenital dysplasia of hip, risk factors, twins

\section{Introduction}

The risk of developing hip dysplasia or luxation has been discussed in the literature in connection with various risk factors. A fundamental point raised by several authors is that ultrasound screening of the hips of newborn babies should only be carried out if risk factors are involved and that, in general, screening of all babies is considered unnecessary. ${ }^{1-3}$ Due to the frequent familiar occurrence of dysplasia, much of the work presented in the literature shows the genetically determined component to be an essential risk factor. ${ }^{2-12}$ Breech-position births $s^{2-6,8,10-16}$ and the presence of deformities at birth such as foot deformities, muscular wryneck, newborn scoliosis etc ${ }^{3,7,11}$ have been thought by many to be closely connected with simultaneously existing hip dysplasia. Of the postulated clinical signs such as leg length discrepancies, abduction impediment and asymmetry, duplication asymmetry and Ortolani phenomena, only the latter can be recognised as justified and this only with decentred hips. The other clinical signs indicate a large number of

Correspondence: Dr Oliver Rühmann, Orthopaedic Department, Hannover Medical School, Heimchenstr. 1-7, D-30625 Hannover, Germany. Tel: + +5115354340; Fax: + +5115354682; E-mail: ruehmann@annastift.de

Received 12 November 1998; revised 29 May 1999; accepted 4 July 1999 incorrect positive and negative results, particularly regarding dysplasia with centred hips., ${ }^{6,17-20}$ With reference to prematurely born babies, there is a higher rate of undeveloped hip joints without any increased sonographical pathology, indicating that the general statements of some authors do not necessarily apply to a specific risk group. ${ }^{6,13,18}$

With twin pregnancies there is a high probability of breech presentation and an increased intrauterine pressure, suggesting that twins have a greater risk of hip dysplasia formation. ${ }^{6}$

Most of the articles on the subject do not cover in detail the correlation between twin pregnancy and hip dysplasia. In this study, the results of an instituted sonographic hip screening programme including a twin cohort, are presented, with special regard to the following questions. Do twins have a higher rate of hip congenital dysplasia than singletons? Is there an effect among twins due to prematurity, breech delivery and cases of dysplasia in their families?

\section{Materials and methods}

We examined the hips of newborn babies of the department of gynaecology and obstetrics at Hannover Medical School. 
Table 1 Ultrasound examination. Definition of types of hip according to Graf's technique and classification. Consequences for the particular types of hip

\begin{tabular}{lll}
\hline Type of hip & Definition & Consequence \\
\hline Ia, Ib & normal joint & no control investigation \\
$\mathrm{Ila}+$ & physiologically immature hip, appropriate for age & type Ila, al pha $\geq 55^{\circ}:$ control investigation after 6 weeks \\
$\mathrm{Ila}-$ & maturation deficiency exceeds tolerable degree & type IIa, al pha $<55^{\circ}:$ control investigation within 4 weeks \\
IIc & minimum degree of maturation at birth not reached & abduction orthosis \\
$\mathrm{D}$ & beginning partial dislocation (subluxation) & Pavlik harness accompanying physiotherapy \\
IIIa, IIIb & partial dislocation (subluxation) & Pavlik harness accompanying physiotherapy \\
IV & dislocation (luxation) & Pavlik harness or extension accompanying physiotherapy \\
\hline
\end{tabular}

Between July 1987 and March 1996, 13864 babies were born; 4476 of them (2260 male, 2216 female) underwent an ultrasound examination of the hips performed by 19 different physicians of the orthopaedic department. All available newborns except those al ready discharged or those absent due to treatment in intensive care, for example, were examined as an unselected group. The investigations took place every second day, with $95 \%$ of the newborns being examined within 5 days of birth. No special inclusion or exclusion criteria were determined.

Ninety-seven $(2.2 \%)$ of the newborns ( 40 male, $57 \mathrm{female}$ ) were twins. Thirty-nine pairs $(10 \mathrm{male} /$ male, $19 \mathrm{female} / \mathrm{female}, 10 \mathrm{male} / \mathrm{female})$ of twins and 19 individual twin members (6 male, 13 female) were examined. The relation between identical and non-identical twins was not considered.

The ultrasound examinations and diagnosis into hip type were performed according to Graf's technique and classification, ${ }^{21}$ using a $5.0 \mathrm{MHz}$ (Siemens SL-1; Siemens AG, Erlangen, Germany) or $7.5 \mathrm{MHz}$ (Picker LSC 7500; Picker International GmbH, Hofheim-Wallan, Germany) linear transducer.

Available and complete documentation, including data of the newborn, anamnesis, clinical and sonographic findings, consecutive therapy and procedure, was analysed retrospectively and statistically evaluated using the $\chi^{2}$ test.

To reduce variation in assessment and to improve inter-observer agreement, all sonograms and forms were additionally checked immediately after the investigation by an experienced ultrasound examiner and, if necessary, corrected. According to Graf, typesla, Ib and Ila $\left(\alpha \geq 55^{\circ}\right)$ are not pathologic, typella $\left(\alpha<55^{\circ}\right)$ needs an early control examination, and typesIIc, D, IIIa, IIIb, IV require therapy. These classifications of ultrasound examination of
Table 2 Comparison of results of all newborns, singletons and twins, statistical analysis ( $\chi^{2}$ test)

\begin{tabular}{|c|c|c|c|}
\hline Type of hip & $\begin{array}{l}\text { All newborns } \\
n=4476\end{array}$ & $\begin{array}{l}\text { Singletons } \\
n=4379\end{array}$ & $\begin{array}{l}\text { Twins } \\
\mathrm{n}=97\end{array}$ \\
\hline $\mathrm{Ia}, \mathrm{Ib}, \mathrm{IIa}\left(\geq 55^{\circ}\right)$ & $4207(94.0 \%)$ & $4112(93.9 \%)$ & $95(97.9 \%)$ \\
\hline $\begin{array}{l}\text { IIa }\left(<55^{\circ}\right), \mathrm{IIc} \\
\mathrm{D}, \mathrm{IIIa} / \mathrm{b}, \mathrm{IV}\end{array}$ & $269(6.0 \%)$ & $267(6.1 \%)$ & $2(2.2 \%)$ \\
\hline $\begin{array}{l}\text { statistical } \\
\text { analysis }\end{array}$ & \multicolumn{3}{|c|}{$\begin{array}{l}\text { type of hip IIa }\left(\text { alpha }<55^{\circ}\right) \text { to IV: } \\
\text { not significantly more often in twins }(P>0.05)\end{array}$} \\
\hline
\end{tabular}

the hip and the related consequences are summarised in Table1.

\section{Results}

We found types la, Ib, Ila $\left(\alpha \geq 55^{\circ}\right)$ in $4207(94.0 \%)$ of all newborns, in $4112(93.9 \%)$ of the singletons, and in $95(97.9 \%)$ of the twins. Early control examinations and/or therapy (typella $\left(\alpha<55^{\circ}\right)$, IIc, D, IIIa, IIIb, IV) were necessary in $269(6.0 \%)$ cases overall, specifically in $267(6.1 \%)$ singl etons and two (2.1\%) twins (Table 2).

Hips of typella $\left(\alpha<55^{\circ}\right)$, IIc, D, IIIa, IIIb, IV were not found in twins with the following risk factors that are known before birth: breech position birth, family history of $\mathrm{CDH}$, and premature birth (before the 37th week of gestation). Two (3.5\%) female twins and no male twins showed these hips (Tables 3-6).

Twins with or without additional risk factors known before birth did not show significantly more often the types IIa $\left(\alpha<55^{\circ}\right)$, IIc, D, IIIa, IIIb, IV $(P>0.05)$ than did singletons.

Table 3 Comparison of results of female and male newborns of the entire group and the twins $\left(\chi^{2}\right.$ test)

\begin{tabular}{|c|c|c|c|c|}
\hline Type of hip & $\begin{array}{l}\text { Boys } \\
n=2260\end{array}$ & $\begin{array}{l}\text { Girls } \\
n=2216\end{array}$ & $\begin{array}{l}\text { Male twins } \\
\mathrm{n}=40\end{array}$ & $\begin{array}{l}\text { Female twins } \\
\mathrm{n}=57\end{array}$ \\
\hline $\mathrm{Ia}, \mathrm{Ib}, \mathrm{IIa}\left(\geq 55^{\circ}\right)$ & $2185(96.7 \%)$ & $2022(91.2 \%)$ & $40(100 \%)$ & $55(96.5 \%)$ \\
\hline $\mathrm{IIa}\left(<55^{\circ}\right), \mathrm{IIc}, \mathrm{D}, \mathrm{III} \mathrm{a} / \mathrm{b}, \mathrm{IV}$ & $75 \quad(3.3 \%)$ & $194(8.8 \%)$ & 0 & $2(3.5 \%)$ \\
\hline statistical analysis & \multicolumn{4}{|c|}{ type of hip Ila (alpha $\left.<55^{\circ}\right)$ to IV: significantly more often in girls $(\mathrm{P}<0.05)$} \\
\hline
\end{tabular}


Table 4 Comparison of results of all newborns, singletons, twins, and breech presentation at birth, statistical analysis ( $\chi^{2}$ test)

\begin{tabular}{llll}
\hline Type of hip & $\begin{array}{l}\text { All newborns } \\
\mathrm{n}=165\end{array}$ & $\begin{array}{l}\text { Singletons } \\
\mathrm{n}=157\end{array}$ & $\begin{array}{l}\text { Twins } \\
\mathrm{n}=8\end{array}$ \\
\hline $\begin{array}{l}\mathrm{Ia}, \mathrm{Ib}, \mathrm{Ila}\left(\geq 55^{\circ}\right) \\
\mathrm{Ila}\left(<55^{\circ}\right), \mathrm{Ilc},\end{array}$ & $137(83.0 \%)$ & $129(82.2 \%)$ & $8(100 \%)$ \\
$\begin{array}{l}\mathrm{D}, \mathrm{III} / \mathrm{b}, \mathrm{IV} \\
\text { statistical } \\
\text { analysis }\end{array}$ & $\begin{array}{l}28(17.0 \%) \\
\left.\text { type of hip IIa (alpha }<55^{\circ}\right) \text { to IV: } \\
\text { not significantly more often in twins } \\
\text { with breech presentation (P }>0.05)\end{array}$ \\
\hline
\end{tabular}

Table 5 Comparison of results of all newborns, singletons, twins, and cases of dysplasia in their families, statistical analysis $\left(\chi^{2}\right.$ test)

\begin{tabular}{llll}
\hline Type of hip & $\begin{array}{l}\text { All newborns } \\
\mathrm{n}=372\end{array}$ & $\begin{array}{l}\text { Singletons } \\
\mathrm{n}=357\end{array}$ & $\begin{array}{l}\text { Twins } \\
\mathrm{n}=15\end{array}$ \\
\hline $\begin{array}{l}\mathrm{Ia}, \mathrm{Ib}, \mathrm{IIa}\left(\geq 55^{\circ}\right) \\
\mathrm{IIa}\left(<55^{\circ}\right), \mathrm{IIC},\end{array}$ & $332(89.3 \%)$ & $317(88.8 \%)$ & $15(100 \%)$ \\
$\begin{array}{l}\mathrm{D}, \mathrm{III} / \mathrm{b}, \mathrm{IV} \\
\text { statistical } \\
\text { analysis }\end{array}$ & $\begin{array}{l}\left.\text { type of hip IIa (alpha }<55^{\circ}\right) \text { to IV: } \\
\text { not significantly more often in twins } \\
\text { with dysplasia in the family }(\mathrm{P}>0.05)\end{array}$ \\
\hline
\end{tabular}

Table 6 Comparison of results of all newborns, singletons, twins, and premature birth, statistical analysis ( $\chi^{2}$ test)

\begin{tabular}{llll}
\hline Type of hip & $\begin{array}{l}\text { All newborns } \\
\mathrm{n}=240\end{array}$ & $\begin{array}{l}\text { Singletons } \\
\mathrm{n}=204\end{array}$ & $\begin{array}{l}\text { Twins } \\
\mathrm{n}=36\end{array}$ \\
\hline $\begin{array}{l}\mathrm{Ia}, \mathrm{Ib}, \mathrm{IIa}\left(\geq 55^{\circ}\right) \\
\mathrm{Ila}\left(<55^{\circ}\right), \mathrm{Ilc},\end{array}$ & $222(92.5 \%)$ & $186(91.2 \%)$ & $36(100 \%)$ \\
$\begin{array}{l}\mathrm{D}, \mathrm{III} / \mathrm{b}, \mathrm{IV} \\
\text { statistical } \\
\text { analysis }\end{array}$ & $\begin{array}{l}18(7.5 \%) \\
\left.\text { type of hip IIa (al pha }<55^{\circ}\right) \text { to IV: } \\
\text { not significantly more often in twins } \\
\text { with premature birth }(\mathrm{P}>0.05)\end{array}$ \\
\hline
\end{tabular}

\section{Discussion}

Incomplete development of the hips leading to dysplasia did not occur more frequently in twins than in non-twins, despite a high number of breech presentations $(8.3 \%)$ in twins.

With twin pregnancies there is increased intrauterine pressure and frequency of breech presentation. The connection between hip luxation and breech position has been acknowledged for some time, with reports of $12.3 \%$ to $25.0 \%$ of the number of children with congenital hip luxation born in breech position. ${ }^{7,14}$ The majority of authors have deduced from their sonographical investigations that hip dysplasia is more frequent in children born in breech position. ${ }^{2-6,8,10,13-15}$ Morgan $^{22}$ stated in 1964 that $5.8 \%$ of all births in breech position were twins; Roth $^{23}$ found in 1961 that $21 \%$ of all twins are born in breech position. Our team found that $8.3 \%$ of the twins were born in breech position.

The assumption that twins born in breech position demonstrate a higher likelihood of dysplasia and

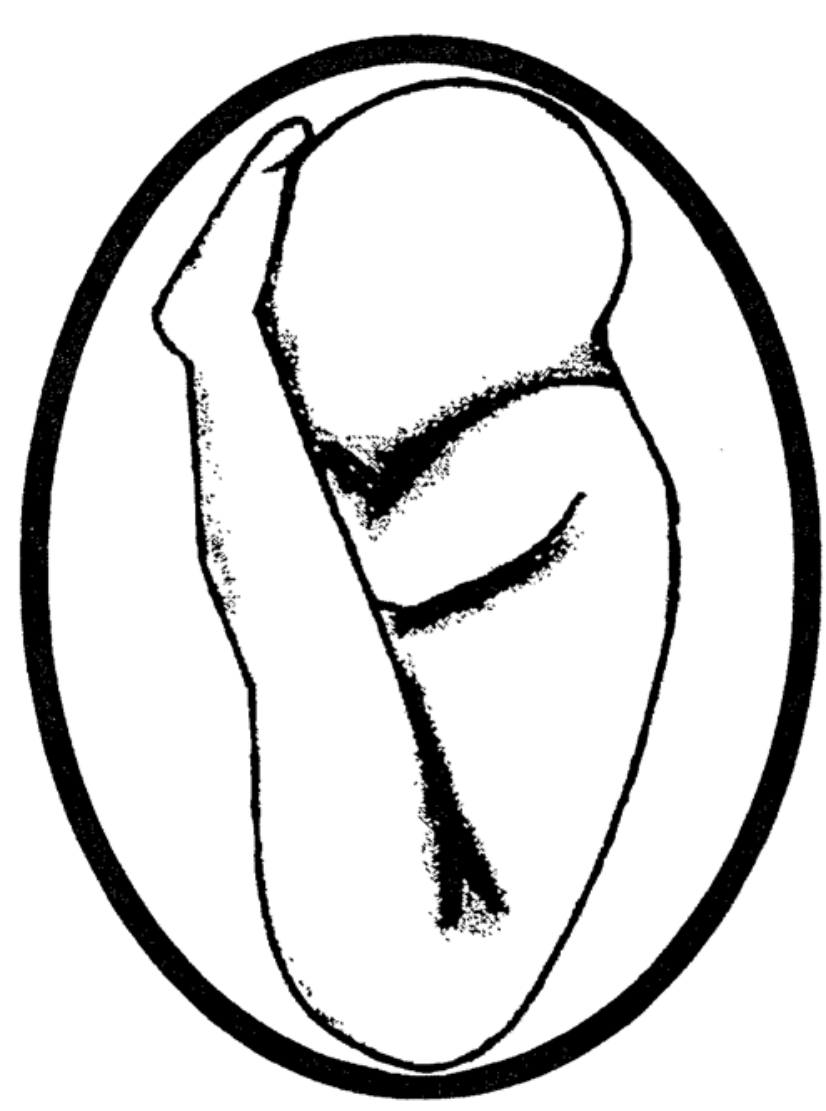

Figure1 Straightforward breech presentation: the legs extended at the knee are stretched upwards to the side of the child's abdomen; predominant breech position in non-twins

luxation was refuted by Fettweiss in 1992 . He suggested that breech presentations of twins are different from those of non-twins. Breech births in singletons are usually straightforward breech presentations, ie the legs extended at the knee are stretched upwards to the side of the child's abdomen (Figure 1). The breech position with flexed hips and fully extended knees represents a special high-risk group for congenital dysplasia of the hip, because the prolonged tension of the ischiocrural musculature mechanically exerts a pressure on the posterior and superior acetabular rim. ${ }^{7,8,15,16,24}$ Depending on the form of the spatial narrowing and length of time in this position, hip dysplasia and/or dislocation can occur. Breech position is usually occupied by singletons long before birth takes place, since in most cases spontaneous turning of the foetus (up to the 32nd week of gestation) does not take place from the breech position into the physiological vertex presentation.

Fettweiss ${ }^{7}$ suggests that for twins, the footling presentation usually prevails with folded legs and parallel positioned feet (Figure2), ie legs positioned as for a vertex presentation. This statement refers to the work of Wilkinson ${ }^{16}$ from 1972, who investigated 


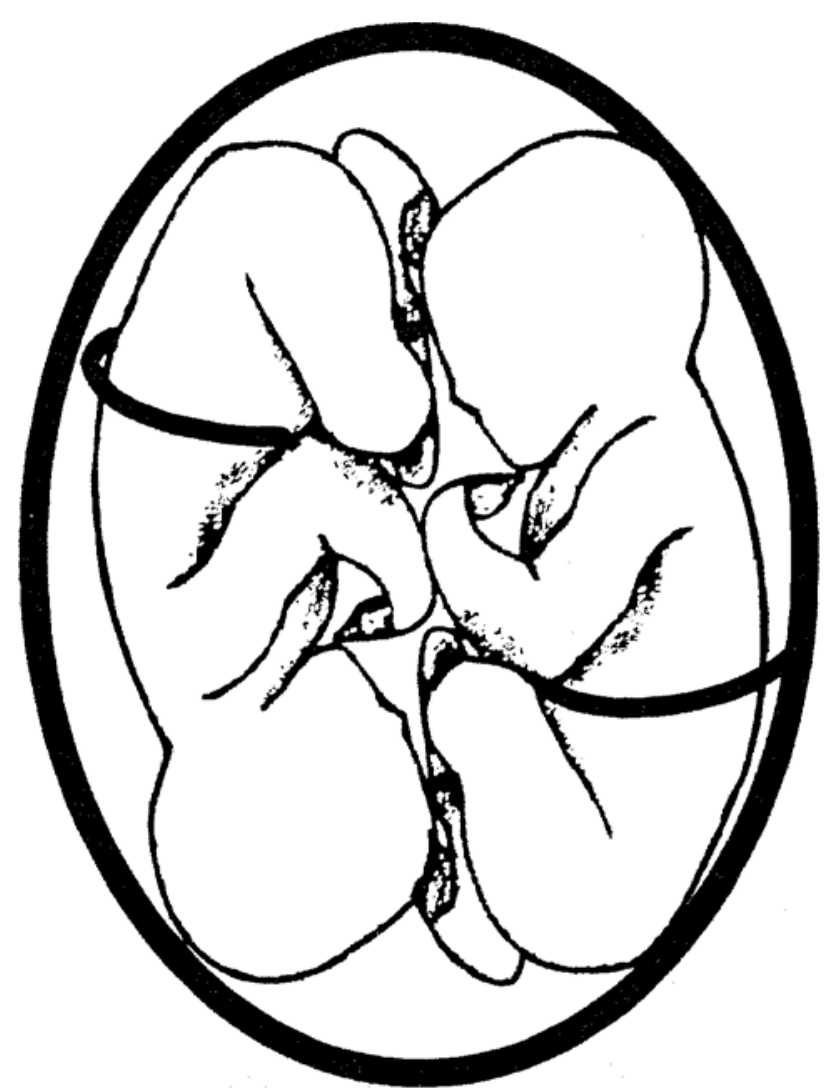

Figure2 Footling presentation with folded legs and parallel positioned feet, ie a leg position as for vertex presentation: predominant breech position in twins

the configuration of newborn babies immediately following birth.

According to Fettweiss, ${ }^{7}$ one can also conclude indirectly from the work of Isigkeit ${ }^{25}$ in 1931 and Idelberger $^{9}$ in 1951 that breech presentation alone is not the sole cause of hip dysplasia for twins. Both stated that there was no increase in the occurrence of muscular wrynecks in twins which is closely associated with breech presentations. Also, in the case of twins as opposed to non-twins, the breech position is usually taken on during or just before birth, resulting in a shorter duration of mechanical strain for the hip. Our group demonstrated that there was a higher percentage of twins born before the 37th week of gestation period (37.1\%), as opposed to singletons $(4.6 \%)$ but no increased rate of hip dysplasia was demonstrated in the twins. Dorn ${ }^{6}$ found in 1990 that there was no indication that premature babies presented a higher risk of hip dysplasia. On the other hand, he suggests that the final months of pregnancy result in an impediment of movement with increased intrauterine narrowing and relatively less amniotic fluid. Pauer ${ }^{13}$ and Pfeil ${ }^{18}$ al so did not find any increased sonographic pathology in the investigated hips of premature babies. We also did not find the types IIa $\left(\alpha<55^{\circ}\right)$, and worse, more often in twins with additional risk factors (family history of $\mathrm{CDH}$, premature birth).

Information is lacking in the literature regarding the occurrence of dysplasia in monovular vs dissimilar twins. In our group the worse types of hip were found in dissimilar twins.

Rosendahl ${ }^{26}$ determined inter- and intra-observer variability in assessing hip morphology by ultrasound. She found a high degree of agreement for morphological classification based on repeated readings of recorded scans by the same observer, whilst the degree of agreement between observers was moderate. The author concluded that a high degree of inter- and intra-observer agreement in classifying hip morphology in general may be achieved in the reading of ultrasound scans. Inter- and intraobserver variability in producing the scans is poorer than for reading. Dorn ${ }^{6}$ also found that correct assessment of recorded scans depends on the experience of the observer. To obtain a high degree of interobserver agreement, it is necessary to have substantial training, attention to detail in the technique, and meticulous evaluation of results. To reduce variation in assessment and to improve interobserver agreement, all our scans and documentation forms were additionally checked after the investigation by an experienced ultrasound examiner and, if necessary, corrected. Each examiner had participated in several instruction courses, with at least the first 50 recordings of scans performed under guidance.

The most important factor for avoiding bias in using Graf's technique is the identification of the anatomic structures and the proper selection of the standard plane, including correct anatomic representation of os ileum and labrum acetabulare. The description of morphology is followed by angular measurement.

In conclusion, twins with or without additional risk factors that are known before birth did not show a significant higher rate of hip dysplasia manifested as types Ila $\left(\alpha<55^{\circ}\right)$ and worse according to Graf's classification.

\section{References}

1 Clarke NM, Clegg J, Al-Calabi AN. Ultrasound screening of hips at risk for $\mathrm{CDH}$. Failure to reduce the incidence of late cases. JBone Jint Surg 1989; 71-B: 9-12.

2 Jones DA. Importance of clicking hip in screening for congenital dislocation of the hip. Lancet 1989; 1(8638): 599-601.

3 Jones DA, Powell N. Ultrasound and neonatal hip screening. A prospective study of 'high risk' babies. JBone Joint Surg 1990; 72-B: 457-459.

4 Boeree NR, Clarke NMP. Ultrasound imaging and secondary screening for congenital dislocation of the hip. J Bone Jint Surg 1994; 76-B: 525-533. 
5 Burger B, Burger D, Bos CFA, Obermann WR, Rozing PM, Vandenbroucke JP. Neonatal screening and staggered early treatment for congenital dislocation or dysplasia of the hip. Lancet 1990; 336: 1549-1553.

6 Dorn U. Hip screening in neonates. Clinical and sonographic findings. (Hüftscreening bei Neugeborenen. Klinische und sonographische Ergebnisse.). Wien Klin Wschr 1990; 102 (Suppl 181): 1-22.

7 Fettweiss E. Das kindliche Hüftluxationsleiden. Die Behandlung in Sitz-Hock-Stellung. In: Stahl C (ed). Fortschritte in Orthopädie und Traumatologie3. Ecomed Fachverlag: Landsberg/Lech, 1992, pp 9-132.

8 Holen KJ, Tegnander A, Terjesen T, Johansen OJ, Eik-Nes SH. Ultrasonographic evaluation of breech presentation as a risk factor for Hip dysplasia. Acta Paediatr 1996; 85: 225-229.

9 Idelberger $\mathrm{KH}$. Die Erbpathologie der sogenannten angeborenen Hüftverrenkung. Urban und Schwarzenberg: Munich, 1951

10 Rosendahl K, Markestad T, Lie RT. Ultrasound screening for developmental dysplasia of the hip in the neonate: The effect on treatment rate and preval ence of late cases. Pediatrics 1994; 14: 47-52.

11 Tönnis D, Storch K, Ulbrich H. Results of newborn screening for $\mathrm{CDH}$ with and without sonography and correlation of risk factors. J Pediatr Orthop 1990; 10: 145-152.

12 Walter RS, Donaldson JS, Davis CL, Shkolnik A, Binns HJ, Carroll NC, Brouilette RT. Ultrasound screening of high-risk infants. A method to increase early detection of congenital dysplasia of the hip. Am JDis Child 1992; 146: 230-234.

13 Pauer M, Rossak K, Meilchen J. Hip screening of newborns: typing, therapy, and follow-up. [Hüftscreening bei Neugeborenen. Typeneinteilung, Therapie und Verlaufskontrollen]. Z Orthop 1988; 126: 260-265.
14 Record RG, Edwards $\mathrm{H}$. Environmental influences related to the etiology of congenital dislocation of the hip. Brit JPrev Soc Med 1958; 12: 8.

15 Suzuki S, Yamamuro T. Correlation of fetal posture and congenital dislocation of the hip. Acta Orthop Scand 1986; 57 : 81-84.

16 Wilkinson $\mathrm{A}$ A. A postnatal survey for congenital displacement of the Hip. JBone Jint Surg 1972; 54-B: 40-49.

17 Ilfeld FW, West GW, Makin M. Missed or developmental dislocation of the hip. Clin Orthop 1986; 203: 276-281.

18 Pfeil J, Niethard FU, Barthel S. Clinical and sonographic examination of the hip during the first year of life. [Klinische und sonographische Untersuchung der Säuglingshüfte]. Z Orthop 1988; 126: 629-636.

19 Place MJ, Parkin DM, Fitton M. Effectiveness of neonatal screening for congenital dislocation of the hip. Lancet 1978; II: 249-250.

20 Rosendahl K, Markestad T. Congenital dislocation of the hip: a prospective study comparing ultrasound and clinical examination. Acta Paediatr (Norway) 1992; 81: 177-181.

21 Graf R. Fundamentals of sonographic diagnosis of infant hip dysplasia. J Pediatr Orthop 1984; 4: 735-740.

22 Morgan HS, Kane SH. An analysis of 16327 breech births. JAMA 1964; 187: 262-264.

23 Roth F. Statistische Auswertung von über 1000 Beckenendlagengeburten. Schweiz Med Wschr 1961; 91: 1337-1343.

24 Dunn PM. Perinatal observations on the etiology of congenital dislocation of the hip. Clin Orthop 1976; 119: 11-22.

25 Isigkeit E. Untersuchungen über die Heredität orthopädischer Leiden III. Der angeborene Schiefhals. Arch Orthop Unfall Chir 1931; 30: 459.

26 Rosendahl K, Aslaksen A, Lie RT, Markestad T. Reliability of ultrasound in the early diagnosis of developmental dysplasia of the hip. Pediatr Radiol 1995; 25: 219-224. 